\title{
A new combination of endemic species in Ulva from India
}

\author{
Aron Santhosh Kumar $Y^{*}$ and Palanisamy $M$ \\ Botanical Survey of India, Southern Regional Centre, TNAU Campus \\ Coimbatore - 641 003, Tamil Nadu, India \\ *Corresponding author: santhosharon@gmail.com \\ भारत से उल्वा की स्थानिक जाति में नवीन संयोजन \\ अरोन संतोष कुमार वाई एवं पलनीसामी एम
}

\section{सारांश}

प्रस्तुत शोधपत्र में एक नवीन संयोजन उल्वा ओवाटा (थिवी एवं विशालाक्ष्मी एक्स जोशी एवं कृष्णामूति) अरोन संतोष कुमार एवं पलानीसामी को भारत की स्थानिक जाति प्रस्तावित किया गया है।

\section{ABSTRACT}

The present paper proposes a new combination Ulva ovata (Thivy \& Visalakshmi ex Joshi \& Krishnamurthy) Aron Santhosh Kumar \& Palanisamy from the endemic species of India

Keywords: Combination nova, Enteromorpha ovata, Gopnath, Gujarat, India, Ulva ovata

\section{INTRODUCTION}

The genus Ulva L. is a thallophytic, green alga with ubiquitous distribution in the exclusive environment of the marine ecosystem. It is feminine genus of the family Ulvaceae and positioned under the order Ulvales of Chlorophyceae. It is an inimitable genus to classify based on morphological variability expressed in many taxa. There are 408 taxa were recognized under this genus and 84 taxa have been legitimated taxonomically on the basis of standard literatures. A sum of 199 taxa is treated as infraspecific names of this genus (Guiry \& Guiry, 2021).

Link (1820) proposed a new genus through monostromatic blades with tubular thallus into Enteromorpha and he treated distromatic blades with flattened thallus under Ulva. Later, Papenfuss (1960) made a diagnostic study on the status of the order Ulvales and transferred the unrelated taxa from Ulva to other genera. In most of the literature, this genus is treated into two distinct genera i.e., Enteromorpha and Ulva.

Hayden \& al., (2003) ensured the molecular study on the uncertain genera Ulva and Enteromorpha. The obtained sequences of ITS nrDNA from 29 taxa highlighted the simple morphology and high degree of phenotypic plasticity in Ulva. The result of the molecular studies states that both genera have similar molecular orientations. Henceforth, genus Enteromorpha transferred to Ulva, and the same is now followed in wide level.

In India, Joshi \& Krishnamurthy (1972) proposed the novel species Enteromorpha ovata (Holo Type: (NFMAH 607) from the coastline of Gujarat. This species has not been validated in to Ulva because of the lacuna to access the specimen (Hayden \& al., 2003). But, the occurrence and diversity of this species was periodically reported by several researchers in different decades (Silva \& al., 1996; Krishnamurthy, 2000; Oza \& Zaidi, 2001; Jha \& al., 2009; Rao \& Gupta, 2015; Mantri \& al., 2020). The protologue furnished by Joshi \& Krishnamurthy (1972) and descriptions of Krishnamurthy, (2000) and Jha \& al., (2009) evidently support the distinctiveness of E. ovata. Further, GenBank $r c b l$ sequence (HM572265) from Gopnath, Gujarat (www.ncbi.nlm.nih.gov/nuccore/HM572265) confirms the factual identity of this species. Therefore, the uncertain status of Enteromorpha for the Indian species should be treated to Ulva. 
Hence the following combination is proposed as per the articles (6.10 and 41.2) of International Code of Nomenclature for algae, fungi, and plants (Turland $\&$ al., 2018).

\section{NOMENCLATURE TREATMENT}

Ulva ovata (Thivy \& Visalakshmi ex Joshi \& Krishnamurthy) Aron Santhosh Kumar \& Palanisamy, comb. nov.

Enteromorpha ovata Thivy \& Visalakshmi ex Joshi \& Krishnamurthy. Bot. J. Linn. Soc., 65: 119-128.1972.

Type: INDIA: Gujarat, Bhavnagar District, Gopnath, 13.10.1961, Thivy \& Visalakshmi 607 (Holo: NFMAH!)

Distribution: India (Gujarat) - Endemic (Oza \& Zaidi 2001).

Notes: In anatomy, Ulva ovata resembles with Ulva intestinalis, but the single undivided ovate frond and GenBank rcbl sequence (HM572265) from Gopnath, Gujarat are the unique identity of this species. All the type specimens and other herbarium of CSMCRI, Bhavnagar have been shifted to CSMSRI, Marine Algal Research Station, Mandapam, Tamil Nadu.

\section{ACKNOWLEDGEMENTS}

Authors express their sincere gratitude to Director, BSI, Kolkata and Head of Office, BSI, SRC, Coimbatore for support and encouragements. Also, they thankful to Scientist In-Charge, CSMCRI (CSIR), MARS, Mandapam, Ramnad for providing necessary permission and facilities to consult the Herbarium.

\section{REFERENCES}

HAYDEN, H.S., BLOMSTER, J., MAGGS, C.A., SILVA, P.C., STANHOPE, M.J., AND WAALAND, J.R. 2003. Linnaeus was right all along: Ulva and Enteromorpha are not distinct genera. Eur. J. Phycol. 38(3): 277-294.

JOSHI, H.V. AND KRISHNAMURTHY, V. 1972. The species of Enteromorpha from India. J. Linn. Soc., Bot.65: 119-128.

KRISHNAMURTHY, V., 2000. Algae of India and neighboring countries I. Chlorophycota. Oxford \& IBH Publishing Co. Pvt. Ltd., New Delhi.
LINK, H.F. 1820. Epistola ad virum celeberrimum Nees ab Esenbeck...de algis aquaticis, in genera disponendis. In: Nees von Esenbeck C., G., D. (Ed.) Horae physicae berolinenses, Bonnae [Bonn]: Sumtibus Adolphi Marcus.

GUIRY, M.D. AND GUIRY, G.M. 2021-. Algae Base, World-wide electronic publication, National University of Ireland, Galway. http://www.algaebase.org/ (accessed on: 17.04.2021).

JHA, B., C.R.K. REDDY, M.K. THAKUR AND M.U. RAO 2009. Seaweeds of India: The Diversity and Distribution of Seaweeds in Gujarat Coast. CSMCRI, Bhavnagar.

MANTRI, V.A., KAVALE, M.G. AND KAZI, M.A. 2020. Seaweed Biodiversity of India: Reviewing Current Knowledge to Identify Gaps, Challenges, and Opportunities. Diversity 12 \& 13: 1 - 22.

OZA, R.M. AND ZAIDI, S.H. 2001. A Revised Checklist of Indian Marine Algae. CSMCRI, Bhavnagar.

PAPENFUSS, G.F.1960. On the genera of the Ulvales and the status of the order. J. Linn. Soc., Bot. 56(367): 303 318.

RAO, P.S.N. AND GUPTA, R.K. 2015. Algae of India (3): A checklist of Indian Marine Algae (Excluding Diatoms \& Dinoflagellates). Botanical Survey of India, Kolkata.

SILVA, P.C., BASSON P.W., AND MOE, R.L. 1996. Catalogue of the Benthic Marine Algae of the Indian Ocean. University of California press, London.

TURLAND, N. J., WIERSEMA, J. H., BARRIE, F. R., GREUTER, W., HAWKSWORTH, D. L., HERENDEEN, P. S., KNAPP, S., KUSBER, W.-H., LI, D.-Z., MARHOLD, K., MAY, T. W., MCNEILL, J., MONRO, A. M., PRADO, J., PRICE, M. J. AND SMITH, G. F. (Eds.) 2018: International Code of Nomenclature for algae, fungi, and plants (Shenzhen Code) adopted by the Nineteenth International Botanical Congress Shenzhen, China, July 2017. Regnum Vegetabile 159. Glashütten: Koeltz Botanical Books. DOI https://doi.org/10.12705/Code.2018

https://www.ncbi.nlm.nih.gov/nuccore/HM572265 